\title{
Polycyclic aromatic hydrocarbon and microbial load of nat- urally preserved smoked African mud catfish Clarias gar- iepinus (Burchell, 1822)
}

\author{
A. A. AYELOJA*, F. O. A. GEORGE, A. A. AKINYEMI \& O. O. ATANDA \\ (A.A.A.: Department of Aquaculture and Fisheries, University of Ilorin, PMB 1515 Ilorin, \\ Kwara State; F.O.A.G \& A.A.A.: Department of Aquaculture and Fisheries Management, \\ Federal University of Agriculture, Abeokuta (FUNAAB) PO Box 2240 Abeokuta; O.O.A.: \\ College of Naturals and Applied Sciences, McPherson University (MCU) Seriki Sotayo Ogun \\ State) \\ *Correspondingauthor'se-mail:ayeloja2@gmail.com/ayeloja.aa@unlorin.edu.ng
}

\begin{abstract}
Polycyclic Aromatic Hydrocarbon (PAH) and microbial load of naturally preserved smoked African mud catfish (Clarias gariepinus Burchell, 1822) were examined. The experimental design was Complete Randomized Design (CRD) with the treatments been the variously preserved $C$. gariepinus catfish (garlic, ginger, garlic-ginger homogenate preserved and the control without spices). PAH and the microbial load were determined using standard experimental procedures. All PAH values were within internationally recommend value for human consumption, the aerobic mesophilic counts of unpreserved smoked catfish was significantly higher $(\mathrm{p}<0.05)$ than other preserved smoked $C$. gariepinus $(2.51 \pm 0.01-8.98$ $\pm 0.02 \mathrm{log} \mathrm{cfu} / \mathrm{g}$ ); while garlic-ginger preserved smoked catfish product had the lowest aerobic mesophilic counts $(2.48 \pm 0.01-8.92 \pm 0.01 \mathrm{log} \mathrm{cfu} / \mathrm{g})$ during the period of the experiment. Similar trends were observed in the mould fungal, Staphylococcal, coliform, Salmonella and Shigella counts. However, Staphylococcal counts, coliform count and Salmonella and Shigella counts were not detected in the samples at the onset of the experiment. The preserved smoked fish are good and safe for human consumptions when stored at ambient temperatures $\left(25-36^{\circ} \mathrm{C}\right)$ for 56 days. The combination of garlic and ginger provide a much stronger antibiotic effect than the individual ingredients.
\end{abstract}

Keywords: Polycyclic aromatic hydrocarbon; microbial load; naturally preserved; smoked; Clarias gariepinus

Original scientific paper. Received 08 Nov 2018; revised 10 Aug 2019

Introduction

Fish is a very important protein source in the diets of many people in the developing country as it constitutes about $60 \%$ of the total protein intake in adults especially in the rural areas
(Akise et al., 2013). It is a highly proteinous food consumed by a larger percentage of the populace in Nigeria because of its availability and palatability. It also enhances the livelihood of many people and provides foreign exchange

Ghana Jnl Agric. Sci. 54 (2), 15 - 25

GJAS is an Open Access Journal and distributed under the terms of the Creative Commons (CC) License [CC BY 4.0] 
(Fawole et al., 2007 \& Daramola et al., 2014). In Nigeria, fish is eaten fresh, preserved or processed and form a much-cherished delicacy that cuts across socio-economic, age, religious and educational barriers (AdebayoTayo et al., 2008). However, fish is highly perishable especially in the tropics where high temperature and humidity accelerate spoilage of fish immediately after catch (Ayeloja et al., 2015). Daramola et al. (2007) and Ayeloja et al. (2011) stated that poor harvesting, poor storage, chemical breakdown of protein content, fat content (agent of rancidity and off-flavour) and the water content of fish influences rate of fish spoilage. Microbial activity is responsible for spoilage of most fresh fish and of several lightly preserved seafood (Lund et al., 2000). The rate at which fish spoils depends on hygienic conditions, storage temperature, acidity and the structure of the muscular tissue (Daramola et al., 2014). However, the extent of fish damage depends on the processing techniques, the type of fish being processed, weather and mode of storage during transportation (Eyo, 1993 \& Ayeloja et al., 2013). Clarias gariepinus (Catfish) is a very important fresh water fish in Nigeria (Ayeloja et al., 2013a) and enjoys wide acceptability in most of the country because of its unique taste, flavor and texture. The growth of microorganisms and other non-microbial activities such as lipid oxidation contribute to the deterioration of fish products (Jimoh et al., 2012). High ambient temperatures in the tropics also create favourable condition for microorganisms to thrive, which reduces the quality of fish and its potential keeping time leading to food loss (Abolagba et al., 2011).

Preserving food and other perishable products like fish and meat generally involve processes that impede the growth of microorganisms either by the addition of growth-inhibiting ingredients or adjusting storage conditions by freezing or drying (Akise et al., 2013). Microbial analyses of fish and fish products are used by the industry for contractual and internal purposes and by the authorities to check that the microbiological quality is satisfactory (Jimoh et al., 2012). International Commission on Microbiological Specification for Foods (ICMSF), 1986) stated that the maximum recommended bacterial counts for good quality product is 5 $\times 10^{5}\left(5.7 \log _{10} \mathrm{cfu} / \mathrm{g}\right)$, Cheesbrough (2000) also stated that it is generally accepted that fish with microbial load greater than $6 \log _{10}$ cfu/g is likely to be at the stage of being unacceptable from the microbiological point of view and unfit for consumption. Akise et al. (2013) reported that high microbial load and unfavourable composition from smokedried Lutjanus agennes (Red Snapper), Mugil cephalus (Mullet) and Chrysichthys walkeri (Catfish) during shelf storage poses a serious health concern for consumers. There has been an increasing interest on the antibacterial property of plant extracts since the last decade (Lee et al., 2007). Typical examples are the antimicrobial properties of garlic, ginger and lime (Owhe-Ureghe et al., 2010 \& George et al., 2009).

Polycyclic aromatic hydrocarbons (PAH) are formed when complex organic substances are exposed to high temperature or pressure or by the incomplete combustion of woods, coal or oil (Adeosun et al., 2016) while Suchanova et al. (2008) described polycyclic aromatic hydrocarbons (PAHs) as ubiquitous environmental contaminants that are formed during the incomplete combustion of carbonaceous materials. Foods can be contaminated by PAHs from environmental sources, industrial food processing and during home food preparation (Ikechukwu et al., 2012). 
Smoked fish are usually exposed to smoke particles that contain potential carcinogens such as polycyclic aromatic hydrocarbons (PAHs) (Olaoye et al., 2015). Guillen et ai (1997) reported that fish smoked by traditiona techniques usually contain high concentration of PAHs resulting from the source of fue used in their preparation such as charcoal However, there is paucity of information or the polycyclic aromatic hydrocarbons (PAHs concentration of naturally preserved smoker C. gariepinus thus the need for this study This study also seeks to determine the effec of some natural preservatives on the microbia load of smoked African mud catfish Claria gariepinus (Burchell, 1822).

\section{Materials and Methods}

12 live catfish (Clarias gariepinus) with averag. weight of the $226 \pm 23 \mathrm{~g}$ were collected fron an earthen pond and taken (within $43 \mathrm{~min}$ ) t the fish processing unit of the Federal Colleg of Animal Health and Production Technology (FCAH \& PT), Moor Plantation Ibadan where they were prepared in the sequence presented in Fig. $1.6 \mathrm{~kg}$ of dried garlic bulb (Allium sativum) and $10 \mathrm{~kg}$ of dried ginger rhizome (Zingiber officinale) were bought from Bodija market in Ibadan, Oyo State, Nigeria; ground using sterile explosion-proof blender (Waring Products, New Hartford, CT) and later applied to the fish at ratio 1: 20 in accordance with the recommendation of Kumolu-Johnson and Ndimele (2011). Seventy gram each of powdered garlic (A. sativum) and ginger ( $Z$. officinale) were manually homogenized in ratio 1:1. This was applied as preservatives on the catfish before smoking using charcoal as fuel. The experiment was Complete Randomized Design (CRD) where the treatments were the variously preserved catfish (garlic, ginger and mixture of garlic and ginger) with a control (without preservative).

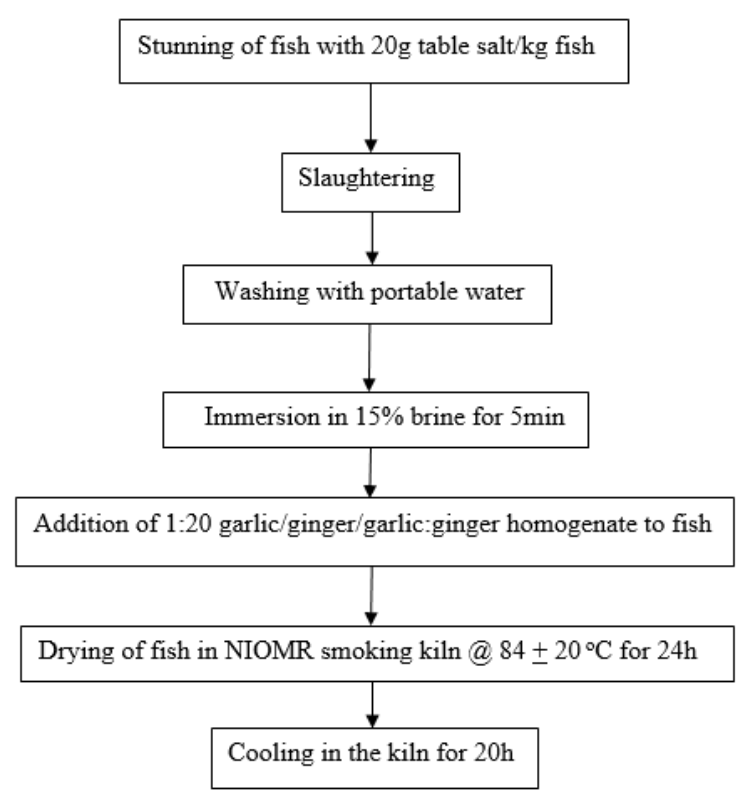

Fig. 1: Flow chart for the production of smoked catfish, Clarias gariepinus

\section{PAH analyses}

Samples of the smoked fish products were collected immediately after smoking and taken to Nigeria Institute for Oceanography and Marine Research (NIOMR) central laboratory for PAH analysis where gas chromatography was used for the analysis.

\section{Microbiological analyses}

Smoked fish products (comprising three samples each of the differently preserved smoked fish product) stored on the shelf at ambient temperature $\left(25-36^{\circ} \mathrm{C}\right)$ were collected at every fortnight (14 days) and taken to the microbiology laboratory for microbiological analysis through 112 days. In the laboratory, 
the fish samples were homogenized after which the aerobic mesophilic counts, mould counts, Staphylococcal counts, coliform count, Salmonella and Shigella counts were determined using routine microbiological procedures described by Olutiola et al. (1991) and Fawole and Osho (1995).

\section{Statistical analysis}

Microbiological data obtained were logarithmically transformed (log $\mathrm{cfu} / \mathrm{g}$ ) and then subjected to Analysis of Variance (ANOVA) while means of the significantly different indices were separated using Duncan Multiple Range Test (DMRT) at $\mathrm{p}<0.05$.

\section{Results and Discussion}

The Polycyclic Aromatic Hydrocarbon (PAH) content (Table 1) of the differently preserved smoked C. gariepinus revealed that benzo -a- pyrene which is highly carcinogenic was highest in the control smoked fish, followed by garlic preserved fish and followed by ginger preserved smoked C. gariepinus, while it was lowest in garlic-ginger preserved smoked C. gariepinus. However, the concentration of benzo (a) pyrene and other PAH in all the smoked fish samples were within internationally recommended value for human consumption of $\leq 2 \mathrm{mg} / \mathrm{kg}$ (ppm) (EFSA, 2002). Silva et al. (2011) reported a similar report where benzo (a) pyrene was not detected in various fish species smoked with different technologies. They also reported that when different sources of fuel were investigated, fish samples that were processed by charcoal gave the lowest level of total polycyclic aromatic hydrocarbons, followed by firewood method, while the sawdust method gave the highest level of total polycyclic aromatic hydrocarbons. This study, therefore, reveals that the various hot- smoked fish products do not constitute a health risk to consumers.

The result of this study as presented in Table 2 indicates that aerobic mesophilic counts of unpreserved smoked catfish which ranges between $2.51 \pm 0.01$ and $8.98 \pm 0.02$ were significantly higher $(\mathrm{p}<0.05)$ than garlicginger preserved smoked catfish (which had the lowest aerobic mesophilic counts ) which ranges between $2.48 \pm 0.01$ and $8.92 \pm 0.01$. Similar, trend was observed in the mould counts, Staphylococcal counts, coliform counts as well as Salmonella and Shigella counts as presented in Tables 3, 4, 5 \& 6 respectively. However, Staphylococcal counts, coliform count as well as Salmonella and Shigella counts were not detected in the samples at the onset of the experiment (Tables 4, $5 \& 6$ ). The result of this study is similar that reported by Fijelu et al. (2014) who observed high levels of microorganisms on unpreserved silver carp samples during storage when compared with garlic and ginger preserved samples and was attributed to strong antimicrobial activity of the organ sulfur compounds and other active components contained in garlic and ginger. Similarly, Kumolu-Johnson and Ndimele (2011) reported that microbial loads of fish samples treated with ginger were significantly $(p<0.05)$ lower than the control which was not treated with ginger. Tagoe et al. (2011) opined that the anti-fungal activity of ginger could be attributed to its chemical properties. Tagoe et al. (2011) also reported similar findings in their study of the anti-fungal properties of onion (Allium cepa), garlic (Allium sativum) and ginger (Zingiger officinale) against Aspergillus flavus, Aspergillus niger and Cladosporium herbarum where it was reported that extracts of plants origin were effective in retarding the growth of those fungi. Kumolu-Johnson 
and Ndimele (2011) also stated that ginger (Zingiber officinale) has some anti-oxidative and anti-fungal effects which can retard oxidative rancidity, inhibit fungal growth, impact acceptable flavour and extend shelflife of fish like Clarias gariepinus. Amit et al. (2011) and Fijelu et al. (2014) reported that the major components of ginger gingerone and gingerol which have strong inhibitory activity against pathogenic bacteria and that the major antimicrobial compound in garlic is allicin through their combined antioxidant and antimicrobial effects in fresh and powder form are potentially good and useful preservatives for smoked fish. The result in Table 2 indicates that the aerobic mesophilic counts from all the fish products were more than the fungi count. This is in line with the findings of Abolagba and Uwagbai (2011) where it was reported that the mean total microbial count in colonyforming unit per gram of the fish sample was highest for bacteria when compared with that of fungi. The results of total plate count (aerobic mesophilic counts) of the fish products were lowest for the first day and these increased significantly $(\mathrm{P}<0.05)$ up till the end of the experiment. Similar trend was obtained for fungi count. This is in accordance with the report of Hood et al., (1983) that microbial load increases with duration of storage and temperature. The study also indicates that the aerobic mesophilic counts is still satisfactory in line with the guidelines for the microbiological quality of some ready-to-eat foods right from the start of the experiment by the International Commission on Microbiological Specification for Foods (ICMSF) 1986, while they had gone beyond maximum recommended bacterial counts for good quality product which is $5 \times 10^{5}$ $\left(5.7 \log _{10} \mathrm{cfu} / \mathrm{g}\right)$ after day 70 of the experiment. SaVarnam and Evans (1991) stated that
Staphylococcus aureus in food products causes health problems when it reaches high levels ( $>5$ $\log _{10} \mathrm{cfu} / \mathrm{g}$ ) in products prepared by hand under bad conditions and can cause food poisoning, this level was attained after 70 days of the experiment indicating that all these products are safe for human consumption up till 70 days of storage. Some of the microorganisms reported in this study were also reported by other scientists as microorganisms associated with smoked fish (Martin, 1994; Abolagba et al., 2011; Okonko \& Okoye, 2001). The increase in the microfloral of smoked C. gariepinus during storage at ambient temperatures could be due to the reabsorption of moisture during storage which eventually encouraged mould growth, (Christianah et al., 2010) expressed similar opinion in their study on the mycological evaluation of smoked fish from the retail outlets in Ago-Iwoye, Ogun State, Nigeria, where they opined that the occurrence of Aspergillus sp, Rhizopus sp, and Penicillium $s p$ could be due to the fact that during storage, the fish sample reabsorbed moisture from the environment which then supported the growth of the microorganisms in addition to the contamination during processing, handling and display on the market stalls. Egbal et al. (2010) also stated that increase in microbiological activity in stored hot-smoked fish was as a result of the increase in water content of the of fish tissues. Hood et al. (1983) gave a similar report that microbial load increases with the duration of storage and temperature. This study indicates that smoking itself elongate the shelf life of fish product as the smoked fish product without preservatives also stayed on the shelf for about 56 days before spoilage. Sengor $e t$ al. (2004) had a similar opinion where it was reported that smoking provides a longer shelf life through its anti-bacterial and oxidative 
effect, lowering of $\mathrm{pH}$, imparting desirable colouration as well as accelerating the drying process and acting as an antagonist to spoilage agents. Hanna (1992) also reported that the storage life extension of smoked fish can be from the combination of lowered water activity and the uptake by the product of bactericidal and antioxidant components of wood smoke. Kumolu-Johnson et al. (2009) also opined that smoking involves heat application to remove water and it inhibits bacterial and enzymatic actions of fish. Fermandez et al. (1997) reported that heat treatment during the preparation of smoked fish would destroy or inactivate most of the pathogens.

\section{CONCLUSION}

This study revealed that the differently preserved smoked catfish are safe for human consumption as the polycyclic aromatic hydrocarbons (PAH) present in them fell within the level recommended for human consumption $(<2 \mathrm{mg} / \mathrm{kg}$ ) by EFSA (2002). Benzo-a-pyrene level which is highly carcinogenic was also very low in the products. The study also indicated that all the smoked fish products stored on shelf at ambient temperatures (25$36^{\circ} \mathrm{C}$ ) are safe for consumptions before 70 days as microbial count studied fell within satisfactory range of ready-to-eat foods recommended by International Commission on Microbiological Specification for Foods (ICMSF, 1986) during 56 days of storage. The combined effects of the homogenate mixture of garlic and ginger in powdery form boost its potency as antimicrobial agent. It is therefore recommended that mixture of garlic and ginger could be used when natural preservation is intended rather than using garlic or ginger singly.

\section{REFERENCES}

Ayeloja, A. A., George, F. O. A., Awobifa, O. M., Sodeeq, A. E., Jimoh, W. A., Shittu, M. A., Abdulsalami, S. A., Sonibare, O. F. \& Adebisi, G. L. (2015) Effect of insect infestation on the economic value of smoked fish sold in selected markets within Oyo state, South West Nigeria. In proceedings of the 30th annual conference of Fisheries Society of Nigeria (FISON) held at ETF lecture theatre, Delta State University, Asaba Campus, Delta State, 23rd - 27th November, 2015.

Abolagba, O. J. \& Uwagbai, E. C. (2011) A comparative analysis of the microbial load of smoke-dried fishes (Ethmalosa fimbriata and Pseudotolithus elongatus) sold in Oba and Koko markets in Edo and Delta States, Nigeria at different seasons. Australian Journal of Basic and Applied Sciences 5 (5), 544 - 550.

Abolagba, O. J., Adekunle, A. T., Dede, A. P. O \& Omoigui, G. O. (2011) Microbial assessment of smoked fish (Clarias spp) in Benin metropolis, Edo State, Nigeria. Journal of Agriculture, Food and Environment 7 (3), 55 -58 .

Adebayo-Tayo, B.C., Onilude, A.A. \& Patrick, U.G. (2008) Mycoflora of smoke dried fishes sold in Uyo, Eastern Nigeria. World Journal of Agricultural Science 4 (3), 346 - 350.

Adeosun, O., Olaifa, F. E. \& Akande. G. R. (2016) Amino acid profile and Polycyclic Aromatic Hydrocarbons (PAHS) of smoked farmed Clarias gariepinus (Burchell, 1822) raised under different culture systems in Ibadan, Nigeria. Journal of Agricultural Science and Environment 16 (2), 69 - 78.

Akise, O. G., Abolagba, O. J. \& Eyong, M. M. (2013) Mycoflora of three fish species smokedried using rubber wood (Hevea Brassillensis) in Nigeria. Greener Journal of Agricultural Sciences 3 (5), 396 - 402.

Amit, K., Ajay, K., Vandana, K., Sandip, P., Chandani, P. \& Anil, K. (2011) Antibacterial 
Polycyclic aromatic hydrocarbon and microbial load...

potential of some natural food preservatives against Staphylococcus aureus isolated from various food samples of Himachal pradesh (India). World Journal of Science and Technology 1 (10), 48 - 53.

Ayeloja, A. A., George, F. O. A., Dauda, T. O. Jimoh, W. A. \& Popoola M. A. (2013a) Nutritional comparison of captured Clarias gariepinus and Oreochromis niloticus. International Journal of Natural Sciences 1 (1), 9 - 13.

Ayeloja, A. A., George, F. O. A., Obasa, S. O., Sanni, L. O. \& Ajayi, A. A. (2011) Effects of length of delay after slaughter (LODAS) on raw catfish (Clarias gariepinus). Journal of American Science 7 (6), 508 - 512.

Ayeloja, A. A., George, F.O.A., Akinyemi, A. A., Jimoh, W. A., Dauda, T. O. \& Akinosho, G. A. (2013) Effect of processing methods on nutritive value of cat fish (Clarias gariepinus). Food Science and Quality Management 11, 31 -38 .

Cheesbrough, M. (2000) District Laboratory Practical in Tropical Countries. Part 2. Cambridge University Press, United Kingdom , $63-70$.

Christianah, I. \& O. E. Fagade (2010) Mycological evaluation of smoked fish from the retail outlets in Ago-Iwoye, Ogun State, Nigeria. Journal of Life and Physical Science. Journal of Life and Physical Sciences 3 (2), 65 - 66.

Daramola, J. A., Alao, F. O., Osofero, S. A. \& Wemimo, O. O. (2014) Assessment of the Microbial and Sensory Qualities of Smoked African Catfish (Clarias gariepinus). Journal of Agriculture and Environmental Sciences 3 (1), $11-22$.

Egbal, O. A., Mohammed, E. A., Regiah, A. K., Hana, M. T. \& Asgad. A. M. (2010) Investigating the quality changes of raw and hot smoked Oreochromis niloticus and Clarias lazera. Pakistan Journal of Nutrition 9 (5), $481-484$.
European Food Safety Authority (EFSA), European Commission (2002) Scientific Committee on Food, Opinion on the risks to human health of polycyclic aromatic hydrocarbons in food.

Eyo, A. A. (1993) Traditional and improved fish handling, preservation and processing techniques. Paper presented at National workshop on fish processing storage, marketing and utilization, pp. 15.

Fawole, M. O. \& Osho, B. A. (1995) Laboratory Manual of Microbiology. Shalom prints Ibadan Nigeria, $25-30$.

Fawole, O. O., Ogundiran, M. A., Ayandiran, T. A. \& Olagunju, O. F. (2007) Proximate and Mineral Composition in Some Selected Fresh Water Fishes in Nigeria. Internet Journal of Food Safety 9, 52 - 55.

Fernandez, C. F., Flick, G.J., Silva, J.L. \& McCaskey, T.A. (1997) Comparison of quality in aquacultured fresh catfish fillets II. Pathogens E.coli 0157: H, campylobacter, vibrio, pleisiomonas and klebiella. Journal of Food Production 60 (10), 1182 - 1188.

Fijelu, F., Yanshun, X., Qixing, J. \& Wenshui, X. (2014) Protective effects of garlic (Allium sativum) and ginger (Zingiber officinale) on physicochemical and microbial attributes of liquid smoked silver carp (Hypophthalmichthys molitrix) wrapped in aluminium foil during chilled storage. African Journal of Food Science 8 (1), 1 - 8.

George, F. O. A., Ephraim, R. N., Obasa, S. O. \& Bankole, M. O. (2009) Antimicrobial properties of some plant extracts on organisms associated with fish spoilage. African Journals online 2 (1), 1 - 9.

Guillen, M. D., Sopelana, P. \& Partearroyo, M. A. (1997) Food as a source of polycyclic aromatic carcinogens. Rev. Environ. Health 12, 133 146. 
Hanna, J. (1992) Rapid microbial methods and fresh fish quality assessment. In: fish processing technology. Hall, G.M (ed). Chapman and Hall, New York, 193 - 211.

Hood, M. A., Ness, G. E., Rodrick, G. E. \& Blake, N. J. (1983) Effects of storage on microbial loads of two commercially important shellfish species, crasspstrea virginica and mercenaria campechiensis. Journal of Applied Environmental Microbiology 45 (4), 1221 1228.

ICMSF (1986) Microorganisms in Foods 2: Sampling for microbiological analysis. Principles and specific applications, $2^{\text {nd }}$ Ed. Oxford: Blackwell Science, pp. 398.

Ikechukwu, A. A., Suleiman, M.T., Dauda B. E., Sadiku, O. S. \& Aberuagba, F. (2012) Effect of extraction methods on the polycyclic aromatic hydrocarbons content of smoked catfish species in Niger State of Nigeria. Jordan Journal of Biological Sciences 5 (1), $71-80$.

Jimoh, W. A., Iyanda, S. A., Adedeji, F. A. \& Ayeloja, A. A. (2012) Mycological evaluation of differently preserved tilapia fish in Abeokuta north local government, Nigeria. Journal of Agricultural Science and Environment 12 (2), $36-44$.

Kumolu-Johnson, C. A. \& Ndimele, P. E. (2011) Anti-oxidative and anti-fungal effect of garlic (Allium sativum) treatment on the shelf life of hot-smoked catfish (Clarias gariepinus, Burchell 1822). World Applied Sciences Journal 13 (7), 1628 - 1634.

Kumolu-Johnson, C.A., Aladetohun, N.F. \& Ndimele, P.E. (2009) The effects of smoking on the nutritional qualities and shelf-life of Clarias gariepinus (Burchell 1822). African Journal of Biotechnology. 9 (1), 73 - 76.

Lee, S., Chang, K., Su, M., Huang, Y. \& Jang, H. (2007) Effects of some Chinese medicinal plant extracts on five different fungi. Journal of Food Control (18), 1547 - 1554.

Lund, B. M., Baird-Parker, T. C. \& Gould, G. W. (Eds) (2000) The microbiological safety and quality of food (1), Aspen Publishers Inc. Gaithersburg, Maryland.

Martin, A.M. (1994) Fisheries processing biotechnological application. Chapman and Hall, London, pp. 494.

Nel, S., Lues, J.F.R., Buys, E.M. \& Venter, P. (2004) Bacterial populations associated with meat from the deboning room of a high throughput red meat abattoir. Journal of Meat Science 66, $667-674$.

Olaoye. O. J., Odebiyi. O. C. \& Abimbola. O. T. (2015) Occupational Hazards and Injuries Associated with Fish Processing in Nigeria. Journal of Aquatic Science 3 (1), 1 - 5.

Okonwo, E. O. \& Okoye, W. I. (2001) Insecticidal activity of dennettia tripetala Baker $f$., piper guineense schum and thonn against dermestes maculatus degeer (Coleoptera: Dermestidae) and necrobia rufipes degeer (Coleoptera: Cleridae) on dried fish. Nigeria Journal of Entomology 18, 109 - 117.

Olutiola, P.O., Famurewa, O. \& Sonntag, H.G. (1991) An introduction to General Microbiology, A Practical Approach. Heidelberger Verlagsanstalt und Druckerei GmbH, Heidelberg, 267.

Owhe-Ureghe, U. B., Ehwarieme, D. A. \& Eboh D. O. (2010) Antibacterial activity of garlic and lime on isolates of extracted carious teeth. African Journal of Biotechnology 9 (21), 3163 $-3166$.

SaVarnam, A. H. \& Evans, M. G. (1991) Food borne Pathogens. The Netherlands. Wolf Science Book, pp. 203.

Sengor, G. , Kalafatoglu, H. \& Gun, H. (2004) The 
Polycyclic aromatic hydrocarbon and microbial load...

determination of microbial flora, water activity and chemical analysis in smoked mussels (Mytilus galloprovincialis, L.). Turkish Journal of Veterinary and Animal Science 28, $793-797$.

Shale, K., Lues, J.F.R., Venter, P. \& Buys, E.M. (2005) The distribution of Staphylococcus spp. on bovine meat from abattoir deboning rooms. Food Microbiology 22, $433-438$.

Silva, B. O., Adetunde, O. T., Oluseyi, T. O., Olayinka, K. O. \& Alo, B. I. (2011) Effects of the methods of smoking on the levels of polycyclic aromatic hydrocarbons (PAHs) in some locally consumed fishes in Nigeria. African Journal of Food Science 5 (7), 384 391.
Suchanova, M., Jana, I., H., Tomaniova, M., Kocourek, V. \& Babika, L. M., Jana, l., H., Tomaniova, M., Kocourek, V. \& Babika, L.(2008) Polycyclic aromatic hydrocarbons in smoked cheese. Journal of Science Food and Agriculture 88 (8), 1307 - 1317.

Tagoe, D. N. A., Nyarko, H. D. \& Akpaka, R. (2011) A comparison of the antifungal properties of onion (Allium cepa), Ginger (Zingiber officinale) and garlic (Allium sativum) against Aspergillus flavus, Aspergillus niger and Cladosporium herbarum. Research Journal of Medicinal Plant 5, 281 - 287.

TABLE 1

PAH content of differently preserved smoked C. gariepinus

\begin{tabular}{llllll}
\hline S/N & PAH & Control mg/kg & $\begin{array}{l}\text { Garlic } \\
\text { preserved } \\
m g / k g\end{array}$ & $\begin{array}{l}\text { Ginger } \\
\text { preserved } \\
m g / k g\end{array}$ & $\begin{array}{l}\text { Garlic-Ginger } \\
\text { preserved } m g / k g\end{array}$ \\
\hline 1 & Naphthalene & 0.0007 & 0.0007 & 0.0024 & 0.0006 \\
2 & Acenaphthylene & ND & 0.0005 & 0.0030 & 0.0014 \\
3 & Acenaphthene & 0.0018 & 0.0020 & 0.0067 & 0.0020 \\
4 & Fluorene & 0.0002 & $\mathrm{ND}$ & 0.0007 & 0.0003 \\
5 & Phenanthrene & 0.0010 & 0.0004 & 0.0008 & 0.0008 \\
6 & Anthracene & 0.0003 & 0.0052 & 0.0004 & 0.0006 \\
7 & Fluoranthene & $\mathrm{ND}$ & 0.0061 & 0.0118 & 0.0006 \\
8 & Pyrene & 0.0024 & 0.0073 & 0.0025 & 0.0054 \\
9 & Benzo(a)anthracene & 0.0003 & 0.0005 & 0.0015 & 0.0006 \\
10 & Chysene & 0.0017 & 0.0002 & 0.0016 & 0.0001 \\
11 & Benzo(b)fluoranthene & 0.0011 & 0.0011 & 0.0006 & 0.0006 \\
12 & Benzo(k)fluoranthene & 0.0013 & 0.0007 & 0.0003 & 0.0006 \\
13 & Benzo(a)pyrene & 0.0037 & 0.0009 & 0.0007 & 0.0004 \\
14 & Dibenz(a,h)anthracene & 0.0030 & 0.0027 & 0.0022 & 0.0025 \\
15 & Indeno(1,2,3-cd)pyrene & 0.0057 & 0.0024 & 0.0016 & 0.0018 \\
16 & Benzo(g,h,i)perylene & 0.0018 & 0.0020 & 0.0036 & 0.0029 \\
\hline
\end{tabular}


TABLE 2

Effect of preservatives on the aerobic mesophilic counts (log cfu/g) smoked catfish stored at ambient for 112days

\begin{tabular}{|c|c|c|c|c|c|c|c|c|c|}
\hline Preservatives & Day 1 & Day 14 & Day 28 & Day 42 & Day 56 & Day 70 & Day 84 & Day 98 & Day 112 \\
\hline Control & $2.51 \pm 0.01^{\mathrm{a}}$ & $2.72 \pm 0.04^{\mathrm{a}}$ & $3.82 \pm 0.03^{\mathrm{a}}$ & $4.64 \pm 0.02^{\mathrm{a}}$ & $5.01 \pm 0.01^{\mathrm{a}}$ & $5.85 \pm 0.01^{\mathrm{a}}$ & $6.75 \pm 0.01^{\mathrm{a}}$ & $7.51 \pm 0.01^{\mathrm{a}}$ & $8.98 \pm 0.02^{\mathrm{a}}$ \\
\hline Garlic & $2.45 \pm 0.03^{\mathrm{ab}}$ & $2.69 \pm 0.07^{\mathrm{a}}$ & $3.76 \pm 0.01^{\mathrm{b}}$ & $4.52 \pm 0.01^{\mathrm{b}}$ & $4.98 \pm 0.02^{\mathrm{b}}$ & $5.83 \pm 0.01^{\mathrm{b}}$ & $6.75 \pm 0.03^{\mathrm{a}}$ & $7.50 \pm 0.03^{\mathrm{ab}}$ & $8.97 \pm 0.01^{\mathrm{b}}$ \\
\hline Ginger & $2.50 \pm 0.02^{\mathrm{ab}}$ & $2.65 \pm 0.05^{\mathrm{a}}$ & $3.70 \pm 0.02^{\mathrm{c}}$ & $4.51 \pm 0.01^{\mathrm{bc}}$ & $4.97 \pm 0.01^{\mathrm{c}}$ & $5.83 \pm 0.01^{b}$ & $6.74 \pm 0.02^{\mathrm{a}}$ & $7.49 \pm 0.01^{b}$ & $8.97 \pm 0.01^{\mathrm{b}}$ \\
\hline Garlic/Ginger & $2.48 \pm 0.01^{\mathrm{b}}$ & $2.64 \pm 0.13^{\mathrm{a}}$ & $3.65 \pm 0.04^{\mathrm{c}}$ & $4.50 \pm 0.01^{\mathrm{c}}$ & $4.93 \pm 0.03^{\mathrm{c}}$ & $5.81 \pm 0.01^{\mathrm{c}}$ & $6.70 \pm 0.01^{\mathrm{b}}$ & $7.44 \pm 0.02^{\mathrm{c}}$ & $8.92 \pm 0.01^{\mathrm{c}}$ \\
\hline
\end{tabular}

* Values with different superscript in the column indicates significant difference at $\mathrm{P}<0.05$

TABLE 3

Effect of preservatives on the mould counts (log cfu/g) of smoked catfish stored at ambient for 112 days

\begin{tabular}{lccccccccc}
\hline \multicolumn{1}{c}{ Preservatives } & Day 1 & Day 14 & Day 28 & Day 42 & Day 56 & Day 70 & Day 84 & Day 98 & Day 112 \\
\hline Control & $2.17 \pm 0.03^{\mathrm{a}}$ & $2.27 \pm 0.01^{\mathrm{a}}$ & $3.55 \pm 0.01^{\mathrm{a}}$ & $3.89 \pm 0.03^{\mathrm{a}}$ & $3.95 \pm 0.04^{\mathrm{b}}$ & $4.88 \pm 0.02^{\mathrm{a}}$ & $5.00 \pm 0.01^{\mathrm{a}}$ & $5.83 \pm 0.01^{\mathrm{a}}$ & $6.65 \pm 0.01^{\mathrm{a}}$ \\
Garlic & $2.05 \pm 0.01^{\mathrm{b}}$ & $2.21 \pm 0.02^{\mathrm{b}}$ & $3.49 \pm 0.01^{\mathrm{b}}$ & $3.88 \pm 0.01^{\mathrm{a}}$ & $4.61 \pm 0.02^{\mathrm{a}}$ & $4.81 \pm 0.01^{\mathrm{b}}$ & $4.99 \pm 0.02^{\mathrm{a}}$ & $5.80 \pm 0.01^{\mathrm{b}}$ & $6.63 \pm 0.01^{\mathrm{b}}$ \\
Ginger & $2.05 \pm 0.02^{\mathrm{b}}$ & $2.21 \pm 0.02^{\mathrm{b}}$ & $3.45 \pm 0.02^{\mathrm{c}}$ & $3.87 \pm 0.02^{\mathrm{a}}$ & $3.93 \pm 0.03^{\mathrm{b}}$ & $4.80 \pm 0.04^{\mathrm{bc}}$ & $4.99 \pm 0.04^{\mathrm{ab}}$ & $5.81 \pm 0.01^{\mathrm{b}}$ & $6.60 \pm 0.01^{\mathrm{c}}$ \\
Garlic/Ginger & $2.01 \pm 0.01^{\mathrm{b}}$ & $2.14 \pm 0.03^{\mathrm{c}}$ & $3.42 \pm 0.01^{\mathrm{d}}$ & $3.87 \pm 0.04^{\mathrm{a}}$ & $3.96 \pm 0.03^{\mathrm{b}}$ & $4.78 \pm 0.01^{\mathrm{c}}$ & $4.95 \pm 0.01^{\mathrm{d}}$ & $5.55 \pm 0.06^{\mathrm{c}}$ & $6.36 \pm 0.05^{\mathrm{d}}$ \\
\hline
\end{tabular}

* Values with different superscript in the column indicates significant difference at $\mathrm{P}<0$.

TABLE 4

Effect of preservatives on the Staphylococcal counts (log cfu/g) of smoked catfish stored at ambient for 112 days

\begin{tabular}{lllllllll}
\hline Preservatives & Day 14 & \multirow{2}{*}{ Day 28 } & Day 42 & Day 56 & Day 70 & Day 84 & Day 98 & Day 112 \\
\hline Control & $2.28 \pm 0.02^{\mathrm{a}}$ & $3.50 \pm 0.02^{\mathrm{a}}$ & $3.89 \pm 0.04^{\mathrm{a}}$ & $4.25 \pm 0.01^{\mathrm{a}}$ & $4.99 \pm 0.01^{\mathrm{a}}$ & $5.86 \pm 0.03^{\mathrm{a}}$ & $6.51 \pm 0.01^{\mathrm{a}}$ & $6.98 \pm 0.01^{\mathrm{a}}$ \\
Garlic & $2.24 \pm 0.01^{\mathrm{b}}$ & $3.45 \pm 0.02^{\mathrm{b}}$ & $3.83 \pm 0.01^{\mathrm{b}}$ & $4.20 \pm 0.02^{\mathrm{b}}$ & $4.94 \pm 0.02^{\mathrm{b}}$ & $5.75 \pm 0.02^{\mathrm{b}}$ & $6.46 \pm 0.03^{\mathrm{b}}$ & $6.93 \pm 0.02^{\mathrm{b}}$ \\
Ginger & $2.23 \pm 0.01^{\mathrm{b}}$ & $3.44 \pm 0.01^{\mathrm{b}}$ & $3.78 \pm 0.02^{\mathrm{c}}$ & $4.17 \pm 0.01^{\mathrm{c}}$ & $4.96 \pm 0.01^{\mathrm{b}}$ & $5.74 \pm 0.04^{\mathrm{b}}$ & $6.42 \pm 0.03^{\mathrm{c}}$ & $6.93 \pm 0.01^{\mathrm{b}}$ \\
Garlic/Ginger & $2.20 \pm 0.02^{\mathrm{c}}$ & $3.34 \pm 0.03^{\mathrm{b}}$ & $3.79 \pm 0.01^{\mathrm{c}}$ & $4.17 \pm 0.01^{\mathrm{c}}$ & $4.94 \pm 0.03^{\mathrm{b}}$ & $5.74 \pm 0.03^{\mathrm{b}}$ & $6.35 \pm 0.02^{\mathrm{d}}$ & $6.92 \pm 0.04^{\mathrm{b}}$ \\
\hline
\end{tabular}

* Values with different superscript in the column indicates significant difference at $\mathrm{P}<0.05$

TABLE 5

Effect of preservatives on the Coliform count (log cfu/g) of smoked catfish stored at ambient for 112 days

\begin{tabular}{|c|c|c|c|c|c|c|c|}
\hline Preservatives & Day 28 & Day 42 & Day 56 & Day 70 & Day 84 & Day 98 & Day 112 \\
\hline Control & $2.41 \pm 0.03^{\mathrm{a}}$ & $2.77 \pm 0.02^{\mathrm{a}}$ & $3.65 \pm 0.01^{\mathrm{a}}$ & $3.95 \pm 0.01^{\mathrm{a}}$ & $4.44 \pm 0.01^{\mathrm{a}}$ & $4.92 \pm 0.03^{\mathrm{a}}$ & $5.69 \pm 0.03^{\mathrm{a}}$ \\
\hline Garlic & $2.33 \pm 0.02^{\mathrm{b}}$ & $2.71 \pm 0.02^{\mathrm{b}}$ & $3.63 \pm 0.03^{\mathrm{a}}$ & $3.91 \pm 0.01^{\mathrm{b}}$ & $4.39 \pm 0.02^{\mathrm{b}}$ & $4.89 \pm 0.04^{\mathrm{a}}$ & $5.65 \pm 0.03^{\mathrm{a}}$ \\
\hline Ginger & $2.34 \pm 0.03^{\mathrm{c}}$ & $2.64 \pm 0.04^{\mathrm{c}}$ & $3.58 \pm 0.02^{\mathrm{b}}$ & $3.88 \pm 0.02^{\mathrm{c}}$ & $4.31 \pm 0.03^{\mathrm{c}}$ & $4.83 \pm 0.05^{\mathrm{a}}$ & $5.61 \pm 0.04^{\mathrm{a}}$ \\
\hline Garlic/Ginger & $2.17 \pm 0.01^{\mathrm{d}}$ & $2.42 \pm 0.03^{\mathrm{d}}$ & $3.32 \pm 0.01^{\mathrm{c}}$ & $3.24 \pm 0.01^{\mathrm{d}}$ & $4.08 \pm 0.02^{\mathrm{c}}$ & $4.74 \pm 0.01^{\mathrm{b}}$ & $5.34 \pm 0.01^{\mathrm{b}}$ \\
\hline
\end{tabular}

* Values with different superscript in the column indicates significant difference at $\mathrm{P}<0.05$ 
Polycyclic aromatic hydrocarbon and microbial load...

TABLE 6

Effect of preservatives on Salmonella/shigella counts (log cfu/g) of smoked catfish stored at ambient for 112 days

\begin{tabular}{lcccccc}
\hline Preservatives & Day 42 & Day 56 & Day 70 & Day 84 & Day 98 & Day 112 \\
\hline Control & $2.56 \pm 0.03^{\mathrm{a}}$ & $2.99 \pm 0.01^{\mathrm{a}}$ & $3.56 \pm 0.01^{\mathrm{a}}$ & $3.89 \pm 0.02^{\mathrm{a}}$ & $4.67 \pm 0.02^{\mathrm{a}}$ & $5.55 \pm 0.01^{\mathrm{a}}$ \\
Garlic & $2.49 \pm 0.01^{\mathrm{b}}$ & $2.93 \pm 0.02^{\mathrm{b}}$ & $3.53 \pm 0.01^{\mathrm{b}}$ & $3.86 \pm 0.02^{\mathrm{b}}$ & $4.60 \pm 0.03^{\mathrm{b}}$ & $5.45 \pm 0.04^{\mathrm{a}}$ \\
Ginger & $2.47 \pm 0.2^{\mathrm{b}}$ & $2.90 \pm 0.01^{\mathrm{c}}$ & $3.50 \pm 0.02^{\mathrm{c}}$ & $3.85 \pm 0.03^{\mathrm{b}}$ & $4.55 \pm 0.02^{\mathrm{c}}$ & $5.42 \pm 0.03^{\mathrm{a}}$ \\
Garlic/Ginger & $2.40 \pm 0.03^{\mathrm{c}}$ & $2.70 \pm 0.03^{\mathrm{d}}$ & $3.38 \pm 0.01^{\mathrm{d}}$ & $3.85 \pm 0.01^{\mathrm{b}}$ & $4.37 \pm 0.04^{\mathrm{d}}$ & $5.22 \pm 0.02^{\mathrm{b}}$ \\
\hline
\end{tabular}

* Values with different superscript in the column indicates significant difference at $\mathrm{P}<0.05$ 